\title{
A review on modern heat-insulating materials for improving the energy efficiency of buildings and life-support utilities
}

\author{
Denis Karpov ${ }^{1, *}$, Olga Dyudina ${ }^{2}$, and Mikhail Pavlov ${ }^{1}$ \\ ${ }^{1}$ Vologda State University, Lenina Street 15, Vologda, 160000, Russia \\ ${ }^{2}$ Kazan State Power Engineering University, Kazan, Russian Federation
}

\begin{abstract}
The main heat engineering characteristics of modern traditional and innovative heat-insulating materials, their advantages, and application fields are considered. Particular attention is paid to liquidceramic heat-insulating materials - thermal paints, which are now actively used for thermal insulation of facades of capital and completed construction projects, engineering and technical life support systems, installations, and separate elements. Interest in the study of this group of building materials is explained by the widespread use of heaters to improve the energy efficiency of civil and industrial buildings, as well as engineering life support systems for various purposes.
\end{abstract}

\section{Introduction}

Modern heat-insulating materials are widely used in construction [1-6]. They make it possible to increase the degree of work industrialization, reduce fuel consumption for heat-ing objects of completed construction, reduce heat losses in engineering networks and in-dustrial units, and provide an appropriate temperature and humidity regime in residential premises of civil buildings.

Nowadays, there exist a fairly large number of both traditional and innovative heat-insulating materials [7-9]. These materials should meet the strict requirements on their sound insulation, incombustibility, water repellency, hygiene, environmental safety. They should have high heat-insulating properties, long service life, ease of installation, corrosion protection, wide temperature range of application, etc. [10,11].

A review and analysis of the market of heatinsulators in the Russian Federation showed that the mineral wool products are now mainly used, their share in the total volume of production and consumption is more than $65 \%$. Glass wool materials account for about $8 \%$, polystyrene foam and other foam layers account for about $20 \%[5,10,11]$.

\section{Materials and methods}

This paper considers various types of heat-insulating materials. The performed analysis of technical literature allowed us to compare their technical characteristics, advantages and scope of application.

\section{Results and discussion}

Consider and analyze the well-known classical and innovative heat-insulating ma-terials.

1. Thermal insulator made of URSA fiberglass (Uralita, Spain), Figure 1,a). Given the material structure and the fibers characteristics, URSA Glasswool staple fiber products have a number of advantages: high heat insulation with low weight, effective sound insula-tion in structures and excellent sound absorption. The elasticity and compressibility of the material guarantee the closest fit of the material to the surface being insulated, which en-sures that there are no gaps and leaks between adjacent mats. The material can be compressed during packaging up to six times, thereby it can significantly save space during transportation.

Its advantages include increased environmental friendliness; high acoustic and heat-insulating characteristics; non-combustibility. It does not contain phenol and formalde-hyde; does not prick; practically does not form dust; does not have a smell. It is pleasant to touch; resembles natural cotton or wool. Its service life is more than 50 years.

Thermal insulator made of URSA fiberglass can be used in plaster-type external insula-tion systems (wet facade, heat-insulating composite facade system with external plaster layers); as a heat-insulating layer in hinged ventilated facades; as thermal insulation of industrial equipment, reservoirs and pipelines of heating networks, oil and gas main pipe-lines, technological pipelines of power plants, metallurgical, petrochemical, industrial en-terprises.

2. Insulating shell made of polyurethane foam (PU foam), Figure 1,b). Shells made of PU foam are rigid cylinders, half-cylinders or segments with a length of

\footnotetext{
*Corresponding author: karpov_denis_85@mail.ru
} 


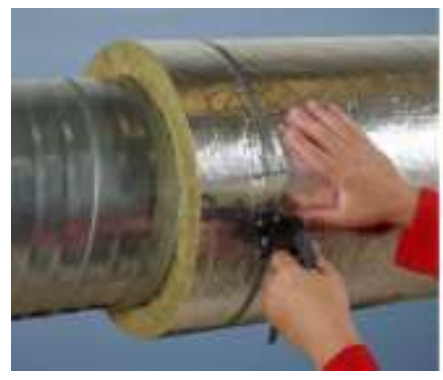

$a$

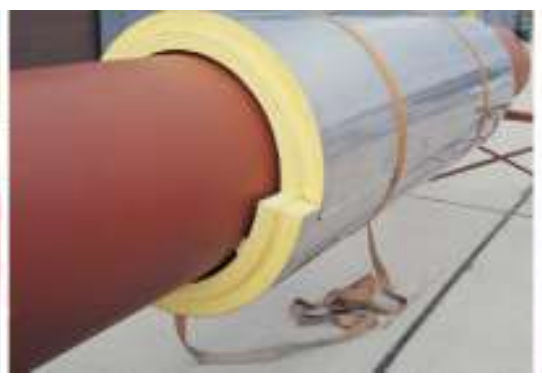

$b$

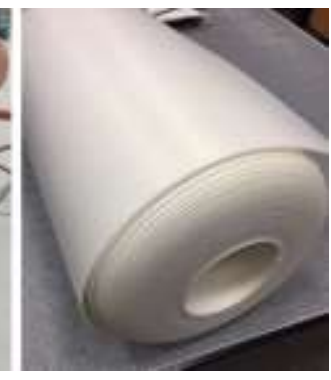

c

Fig. 1. Mineral wool and polymer heat-insulating materials: a) URSA heat-insulating; b) Polyurethane foam; c) Polyethylene foam.

$1000 \mathrm{~mm}$, thick-ness exceeding $30 \mathrm{~mm}$, with longitudinal and transverse locks. The heat-insulating charac-teristics of shells made of rigid PU foam with a thickness of $40 \mathrm{~mm}$ correspond to that of cylinders of mineral stone wool with a thickness of $100 \mathrm{~mm}$, and, in contrast to them, do not change their thermophysical characteristics for a long period of time.

It has the following advantages: the possibility of year-round installation; quick installation by fixing the polyurethane foam shell on the pipe with ties, special polymer adhesives, brackets (two workers per shift can insulate at least $300 \mathrm{~mm}$ of the pipeline without special skills, the material is absolutely harmless to humans); quick access to dam-aged pipes - fistulas and cracks; no effect of "winter soaring" (snow on the pipeline, insulated with PU insulation, does not melt, unlike on mineral wool). It is environmentally friendly. The PU foam shells can be reusable. The service life is 10 years.

It can be used for heat-insulating of hot water supply and heating pipelines, oil pipelines with a pipe diameter from $32 \mathrm{~mm}$ to $1020 \mathrm{~mm}$.

3. Polyethylene foam Izokom P (Izotrade, Russian Federation, Moscow), Figure 1,c). Polyethylene foam (PE foam) is a gas-filled thermoplastic polymer with a closed-porous structure, a soft and elastic material with excellent shock-absorbing properties. Polyeth-ylene foam insulation is a product with a closed-cell structure. It is obtained by injection molding or extrusion of a foamed mass from various ethylene polymers (LDPE, HDPE, etc.), mainly from low density polyethylene with the addition of special additives to im-prove its properties.

It has the following advantages: environmental friendliness, chemical inertness; compatibility with any building material (wood, concrete, gypsum, lime, cement, etc.), stability of heat-insulating and acoustic indicators, moisture resistance and hydrophobicity. It is firm and elastic, resistant to decay; the presence of additive flame retardants in the material increases its fire safety. It has optimal dimensions and low weight, as for sound insulation, the impact noise reduction index is 22$26 \mathrm{~dB}$. The service life is more than 50 years.

It can be used for heat-insulating of floors (for example, as a substrate for laminate, parquet), partitions (middle layer in sandwich panels), pipes for hot and cold water supply, sewerage. It can be also used for insulation and prevention of moisture condensation on the roof, for packaging fragile products, structures, etc.

4. Heat-insulating from Armaflex rubber (Armacell, Germany), Figure 2. It is produced based on expanded synthetic rubber with a closed-cell structure. It is flexible and durable. The high-quality closed-cell structure provides the insulation with highly effective heatinsulating properties. The technical characteristics of the material provide excellent insula-tion and condensation control. Armaflex heat-insulating is a low-flammable, self-extinguishing material.

It has the following advantages: environmental friendliness; high degree of protection against diffusion of water vapor; flexibility of the material; hygiene; corrosion protection; simplicity, cleanliness, ease of installation. The service life is 25 years.

It can be used for heat-insulating of heating systems (up to $105^{\circ} \mathrm{C}$ ), all types of water supply, air conditioning and ventilation. Foamed synthetic rubber Armaflex is the best protection against condensation today, which is why it has been used all over the world for more than 50 years to insulate pipelines with "cold" coolants: cold water, freons, glycols, ammonia.

5. Thermal insulator made of K-flex rubber (L'isolante K-flex, Italy), Figure 2. It is pro-duced from closed-cell foam rubber.

It has the following advantages: environmental friendliness; steam and water resistance; the ability to self-extinguish in case of fire; resistance to microorganisms, mold and weather conditions; a large selection of standard sizes (elastic rubber tubes of various diameters and sheets of foamed synthetic rubber); ease of installation. The service life is 20 years.

It can be used for thermal and sound insulation both in residential and industrial premises, pipelines in heating systems, air ducts in ventilation and air conditioning systems; in refrigeration systems, petrochemical plants and oil platforms, shipbuilding and public transport.

6. Ecowool Extra (Tyumen, Russia), Figure 3, a),b). Cellulose heat insulation (cellulose wool, ecowool) is a loose, lightweight fibrous building insulation material of gray or light gray color. It consists of newsprint (waste paper) (about $80 \%$ ) and non-volatile flame-extinguishing substances $(20 \%)$, which are most often used as boric acid and borax. 


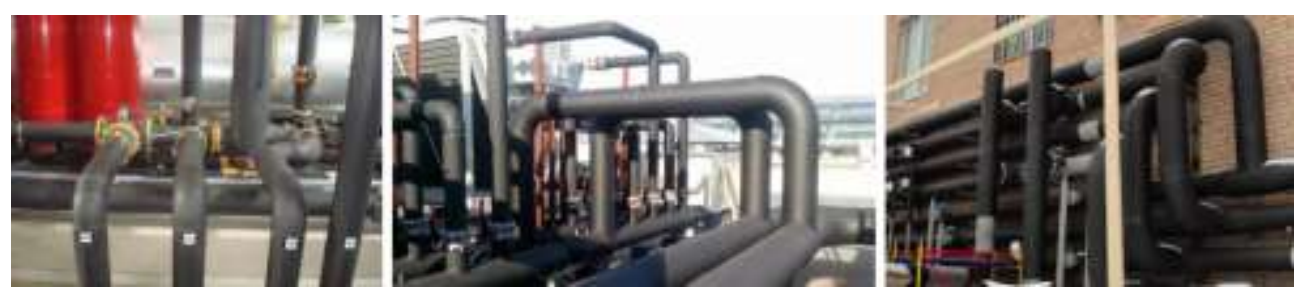

Fig. 2. Synthetic rubber heat-insulating materials.
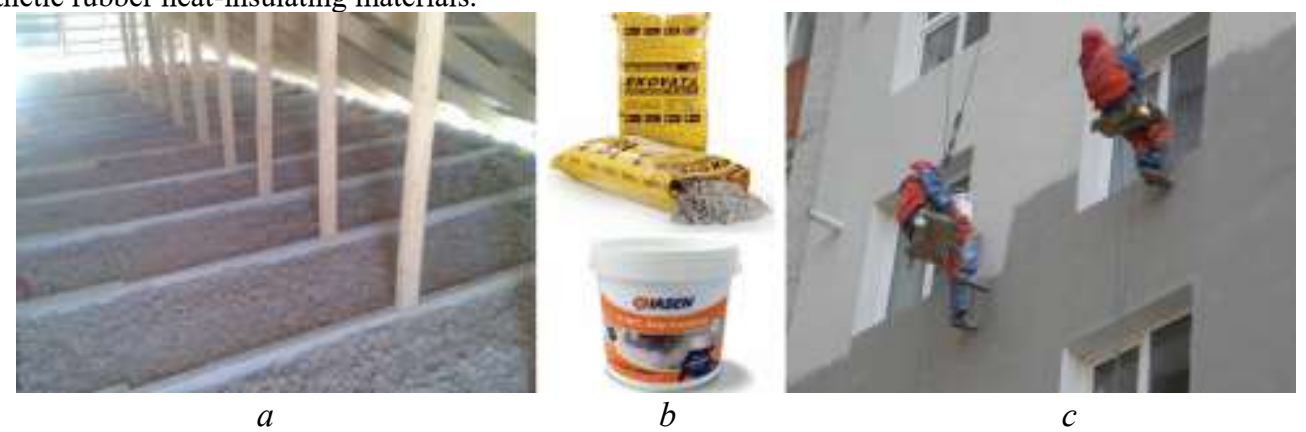

Fig. 3. Ecowool and heat-insulating paint (thermal paint).

It has the following advantages: ecological cleanness; fire safety (the presence of anti-fire components (borax), the resistance of buildings to fire is significantly increased); high sound insulation properties; ease of installation (a house with an area of $150 \mathrm{~m} 2$ is completely covered in one day). The service life is up to 70 years.

It can be used for heat-insulating of ceilings of the lower and upper floors in the con-struction of private and apartment buildings; for insulation of light frame structures, walls; when carrying out reconstruction works of old buildings.

7. Thermal paint Teplomett (Kolomenskiye Kraski, $\mathrm{RF}$, Chelyabinsk), Figure 3,b),c). Teplomett is an ultrathin heat-insulating coating created for a quick and economical solution to the problems of energy saving and heat-insulating of industrial and civil construction objects. Heat transfer in solids can be reduced by using a coating, which weakly conducts thermal energy. To achieve this effect, the Teplomett material contains hollow glass-ceramic, polymer and silicone microspheres of small size and low thermal conductivity. These particles are suspended in a liquid polymer composition and impart increased elasticity, strength and adhesion to the coating without making it heavier. To obtain effective insulation, the average paint consumption should be 1.7-2.2 1 per $1 \mathrm{~m}^{2}$ of the surface to be insulated.

It has the following advantages: environmental friendliness; low coefficient of thermal conductivity $0.0012 \mathrm{~W} /(\mathrm{m} \cdot \mathrm{K})$; wide range of applications. For example, Teplomett Standard is used for any surfaces at temperatures from $5{ }^{\circ} \mathrm{C}$ to $100{ }^{\circ} \mathrm{C}$. Teplomett Facade is used for facade works at temperatures from $5{ }^{\circ} \mathrm{C}$ and above. Teplomett Nord is applied at temperatures from $20{ }^{\circ} \mathrm{C}$ and above. Teplomett 400 is operated up to a temperature of $420^{\circ} \mathrm{C}$. The service life is 10 years in a moderately cold climate and 25 years indoors.
It can be used for heat-insulating and protection of various kinds of tanks, cisterns and other containers for storage and transportation of oil products, liquefied gas, chemicals, drinking and industrial water, and other liquids; processing of industrial equipment; protection of vehicles from temperature extremes, corrosion, condensation, excessive heating; reduction of heat loss in residential buildings by processing facades or interior walls of premises, ceilings, roofs and floors; insulation of balconies and loggias, window and door slopes, terraces and verandas.

\section{Conclusion}

This paper considers some types of heat-insulating materials, which are now used for heat insulation of facades of capital and completed construction projects, engineering and tech-nical life support systems, installations, and separate elements. The choice of heatinsulating material ultimately depends on the goals and objectives of construction, recon-struction, modernization, etc., as well as on the amount of money required for heat-insulating.

\section{References}

1. Sultanguzin, I.A.; Zhigulina, E. V; Yavorovsky, Y. V; Kalyakin, I.D.; Govorin, A. V; Fedyukhin, A. V; Krolin, A.A.; Guzhov, S. V; Derevianko, O.; Mukhametova, L. Development strategy of the energy supply system for MPEI campus blocks based on green building.; 2019; Vol. 288.

2. Ricciu, R.; Besalduch, L.A.; Galatioto, A.; Ciulla, G. Thermal characterization of insulating materials. Renew. Sustain. Energy Rev. 2016, 82, 1765-1773.

3. Agoudjil, B.; Benchabane, A.; Boudenne, A.; Ibos, L.; Fois, M. Renewable materials to reduce building 
heat loss: Characterization of date palm wood. Energy Build. 2011, 43, 491-497, doi:10.1016/j.enbuild.2010.10.014.

4. Heat-insulating Materials and Sound-absorbing Materials. In Building Materials in Civil Engineering; 2011; pp. 304-423.

5. Karpov, D.F. Thermal methods and means of verification the thermal conductivity of the thermal paint. Bull. BSTU named after V. G. Shukhov 2019, 2 , 61-68, doi:https://doi:10.12737/article_5c73fc15ccba41.40 690275.

6. Pavlov, M.; Karpov, D.; Akhmetova, I.; Monarkin, $\mathrm{N}$. Assessment of energy efficiency of application heat-insulating paint for the needs of district heat supply systems. E3S Web Conf. 2020, 178, doi:10.1051/e3sconf/202017801004.

7. Asdrubali, F.; D’Alessandro, F.; Schiavoni, S. A review of unconventional sustainable building insulation materials. Sustain. Mater. Technol. 2015, doi:10.1016/j.susmat.2015.05.002.

8. Gudkov, P.; Kagan, P.; Pilipenko, A.; Zhukova, E.Y.; Zinovieva, E.A.; Ushakov, N.A. Usage of thermal isolation systems for low-rise buildings as a component of information models. E3S Web Conf. 2019, 97, 01039, doi:10.1051/e3sconf/20199701039.

9. Voropai, L.; Duryagina, Y.A.; Sinitsyn, A.A.; Yukhtarova, O.S. Development of a new method for producing heat-insulating materials based on highlying peat and fluorine-containing polymers. In Proceedings of the Materials of the All-Russian Scientific and Practical Conference of Students and Young Scientists "Modern Trends in the Development of Chemical Technology, Industrial Ecology and Technosphere Safety"; SPbGUPTD: St. Petersburg, 2020; pp. 310-313.

10. Pavlov, M.V.; Karpov, D.F.; Berezina, V.P. Modern heat-insulating materials for improving the thermal protection properties of building structures and energy efficiency of engineering systems. Pp. 81-87 (2020). In Proceedings of the Scientific and technical problems of improvement and development of gas power supply systems. Collection of scientific works on the materials of the III International Scientific and Practical Conference; SSTU named after Yu. A. Gagarin: Saratov, 2020; pp. 81-87.

11. Pavlov, M.V.; Karpov, D.F.; Mamonova, V.S. Comparative techno-economic analysis of the modern heat-insulating materials. In Proceedings of the Energy: Efficiency, reliability, safety: proceedings of the XXI all-Russian scientifictechnical conference; Tomsk Polytechnic University: Tomsk, 2015; pp. 9-11.

12. Voropai, L., Kuznetsova, O., Sinitsyn, A., ...Atamanyuk, I., Ilyashenko, S, The Influence of the Relative Content of Peat and Mineral Binder on Thermal Insulation Composite Performance
Characteristics, International Journal of Technology, 2020, 11(8), 1 